\title{
PELATIHAN PENGELASAN PEMUDA KARANG TARUNA DI DESA NGAMPEL NGUSIKAN JOMBANG
}

\author{
${ }^{1}$ Basuki, ${ }^{2}$ Retno Eka P, ${ }^{3}$ M. Munib Rosadi, ${ }^{4}$ Fajar Satriya Hadi, ${ }^{5}$ Minto \\ ${ }^{1,2,3,4}$ Program Studi Teknik Mesin, ${ }^{5}$ Program Studi Teknik Industri, Universitas Hasyim Asy'ari Tebuireng \\ Jombang \\ ${ }^{1}$ basuki@unhasy.ac.id
}

\begin{abstract}
Ngampel is one of the villages located in Ngusikan district Jombang regency. Geographically, the livelihood of Ngampel village is that the majority of the population is farming, the background to this community service is the lack of jobs in the village. So that researchers are interested in doing community service about SMAW welding training that targets young people in the village of Ngampel. The purpose of this service is to provide skills so that later it can be used to find work and can be used to open employment in the community. In this service we work with partners in the Ngampel village government which serve as objects and service points. The method used in this service is the method, lecture, question and answer and direct welding practice. The material provided is the operating procedure of the SMAW welding machine, SMAW welding components and various welding joints. The results of this community service is to provide insights on the welding material and welding practices of SMAW to each participant as a provision to be self employed and looking for work.
\end{abstract}

Keywords: community service, welding training, SMAW

\begin{abstract}
Abstrak
Desa Ngampel merupakan salah satu Desa yang berada di Kecamatan Ngusikan Kabupaten Jombang. Secara geografis Desa Ngampel mata pencaharian sebagian besar penduduknya adalah bercocok tanam, yang melatar belakangi pengabdian masyarakat ini adalah masih minimnya lapangan pekerjaan yang ada di Desa tersebut. Sehingga peneliti tertarik untuk melakukan pengabdian masyarakat tentang pelatihan pengelasan SMAW yang sasarannya pada pemuda desa Ngampel. Tujuan dari pengabdian ini adalah memberikan bekal keterampilan agar nantinya bisa digunakan untuk mencari pekerjaan dan dapat digunakan untuk membuka lapangan kerja dimasyarakat. Dalam pengabdian ini kami bekerjasama dengan mitra Pemerintah Desa Ngampel yang dijadikan sebagai obyek dan tempat pengambdian. Metode yang digunakan dalam pengabdian ini adalah metode, ceramah, tanya jawab dan praktik langsung pengelasan. Adapun materi yang diberikan adalah prosedur pengoperasian mesin las SMAW, komponen - komponen las SMAW dan macam-macam sambungan las. Hasil pengabdian masyarakat ini adalah memberikan wawasan tentang materi pengelasan dan praktik pengelasan SMAW pada masing - masing peserta sebagai bekal untuk berwirawasta dan mencari pekerjaan.
\end{abstract}

Kata Kunci : pengabdian masyarakat, pelatihan pengelasan, SMAW

\section{PENDAHULUAN}

Secara geografis Desa Ngampel memiliki jumlah penduduk sekitar 2962 jiwa, dengan luas wilayah desa $1,29 \mathrm{~km}^{2}$. Sebagian besar penduduk mata pencahariannya adalah buruh tani. Dengan kondisi tersebut bisa dipastikan potensi desa ini masih minim sekali sehingga belum bisa dikatakan banyak menyerap tenaga kerja yang berdampak pada kemakmuran yang rendah. Gambaran riil dilapangan banyak usia produktif seperti lulusan SMA dan SMK yang belum bekerja dan ada juga yang sudah bekerja diluar kota. Penyebab masalah ini dipengaruhi oleh dua hal yaitu minimnya lapangan kerja di pedesaan dan lulsan SMA dan SMK yang masih kurang bekal keterampilannya. Melihat kondisi seperti ini sangat memprihatinkan, pengangguran ini sebagian besar dialami oleh pemuda-pemuda yang mempunyai lulusa pendidikan tinggi hal ini disebabkan oleh tidak terpenuhinya kriteria persyaratan kerja. Berikut data menurut hasil survey badan pusat statistik pengangguran terbuka di Indonesia. 


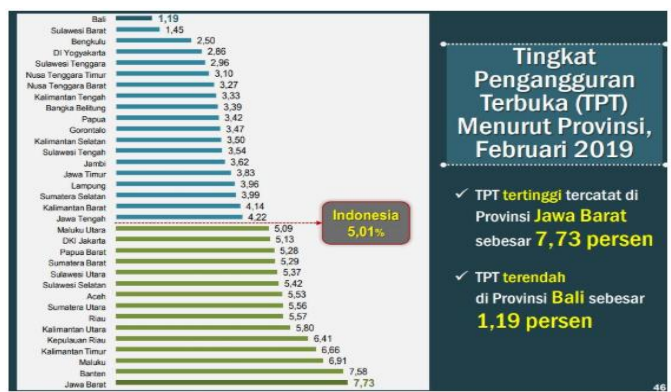

Gambar 1. Pengangguran Terbuka di Indonesia

Sumber:https://www.beritasatu.com/nasional/5 53406/penganggur-terdidik-meningkat.

Diakses tanggal 19 September 2019.

Gambar 1 menunjukkan bahwa tingkat penggangguran tertinggi di Propinsi Jawa Barat sebesar $7,73 \%$, sedangkan pengangguran terendah tercatat di Propinsi Bali sebesar 1,19\%. Selain data tersebut juga bisa disimpulkan bahwasanya pengangguran di Indonesia mencapai 6,8 juta atau $5,01 \%$. Oleh karena itu dengan melihat kondisi seperti itu perlunya dilakukan terobosan-terobosan atau tindakan cepat untuk mengurangi pengangguran yang sudah menyebar di masyarakat. Pemecahan masalah yang ditawarkan dan sesuai dengan kebutuhan masyarakat adalah memberikan pelatihan pengelasan SMAW. Dengan adanya pelatihan ini harapan kami bisa dijadikan sebagai modal atau bekal untuk mencari kerja atau menciptakan lapangan kerja dimasyarakat.

Permasalahan yang timbul pada mitra Desa Ngampel antara lain:

a. Minimnya lapangan kerja di Desa Ngampel

b. Pemuda Desa Ngampel banyak yang menganggur setelah lulus SMA atau SMK

Dengan adanya pelatihan pengelasan SMAW pada pemuda karang taruna Desa Ngampel ini diharapkan dapat memberikan keterampilan dan dapat menumbuhkan jiwa wirausaha.

\section{METODE}

Metode yang digunakan dalam pengabdian ini adalah metode pelatihan, yang artinya selama kegiatan berlangsung disertai dengan demonstrasi atau memberikan percontohan untuk menghasilkan keterampilan. Dalam pelaksanaannya kegiatan pengabdian ini dibagi menjadi tiga tahap yaitu: tahap penyampaian materi pengelasan SMAW, tahap kedua tanya jawab dan tahap praktik atau demonstrasi. Adapun materi yang diberikan kepada peserta antara lain: pengetahuan dasar las SMAW, komponen-komponen las, sambungan las, peralatan $\mathrm{K} 3$.

\section{Waktu dan Tempat Pelaksanaan}

Waktu Pelaksanaan kegiatan pengabdian ini dilakukan pada hari Rabu, tanggal 27 November 2019. Sedangkan lokasi pelaksanaannya di Balai Desa Ngampel, Kecamatan Ngusikan, Kabupaten Jombang.

\section{Alat dan Bahan}

2.1 Alat yang digunakan dalam pengabdian ini antara lain: mesin las SMAW, tang las, palu las, gergaji tangan, sikat las, sarung tangan las, kacamata las atau topeng las, gerinda tangan. Berikut gambar alat beserta kegunaannya

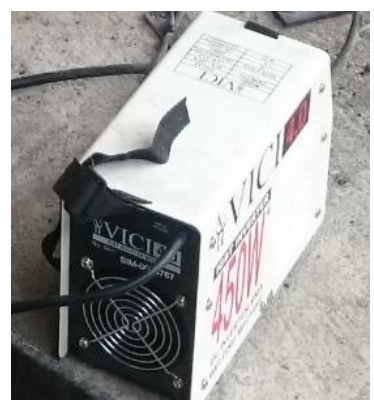

Gambar 1. Las SMAW

Las SMAW berfungsi sebagai mesin las untuk membangkitkan sumber panas yang dihasilkan dari listrik untuk proses penyambungan material logam ferrous dengan cara dipanaskan. 


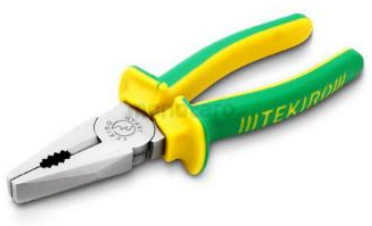

Gambar 2. Tang

Tang berfungsi untuk memegang benda panas setelah hasil pengelasan

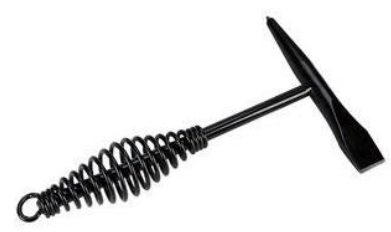

Gambar 3. Palu Las

Palu las berfungsi untuk membersihkan kotoran las atau terak las dengan cara dipukul.

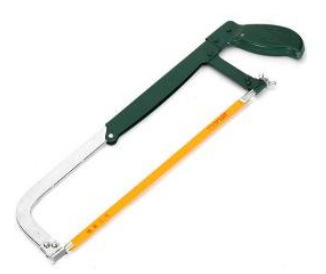

Gambar 4. Gergaji Besi

Gergaji besi berfungsi untuk memotong material logam ferrous yang akan dilas.

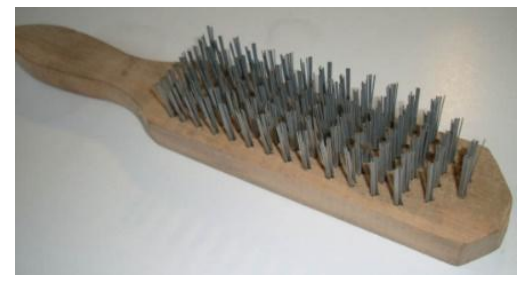

Gambar 5. Sikat Baja Las

Sikat baja las berfungsi untuk membersihkan kampuh las dari kotoran terak dengan cara digosok

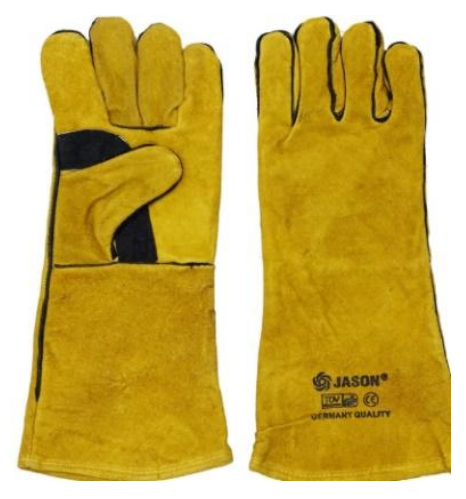

Gambar 6. Sarung Tangan Las

Sarung tangan las berfungsi untuk memegang benda kerja yang akan dilas, supaya tangan tidak panas dan percikan bunga api las.

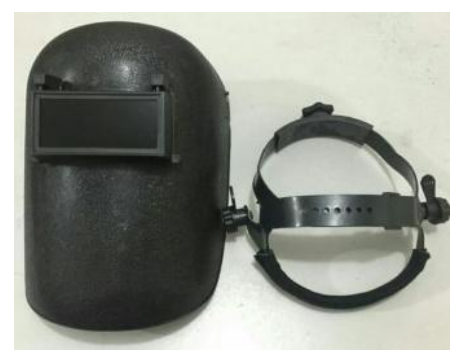

Gambar 7. Topeng Las

Topeng las digunakan untuk melindungi mata dari cahaya las.

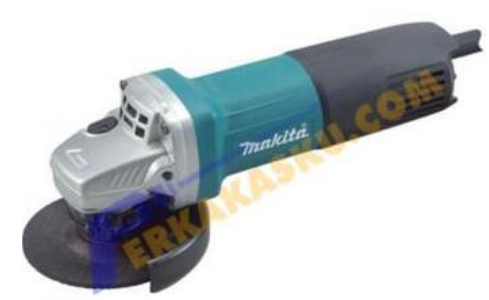

Gambar 8. Gerinda Tangan

Gerinda tangan berfungsi untuk menghaluskan kampuh las pada benda kerja yang selesai dilas.

\subsection{Bahan}

Bahan yang digunakan dalam pengabdian ini antara lain: besi plat dan elektroda. Adapun dimensi besi plat dengan panjang $100 \mathrm{~mm}$, lebar $50 \mathrm{~mm}$ dan tebal $5 \mathrm{~mm}$. 
Pada proses pengelasan ini menggunakan elektroda karbon dengan ukuran 2,6 mm.

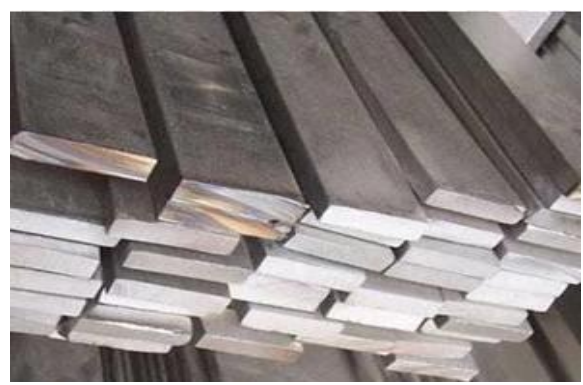

Gambar 9. Besi Plat

Plat digunakan sebagai media pengelasan.

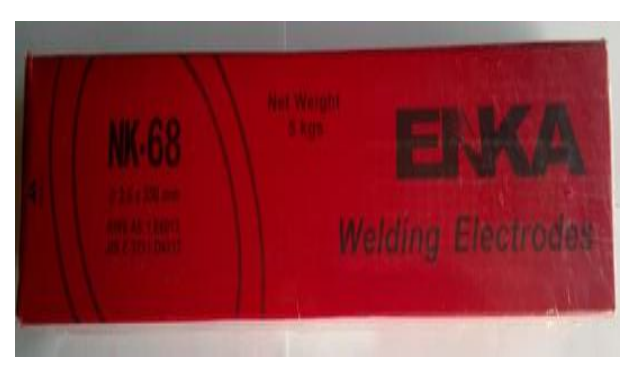

Gambar 10. Elektroda Las

Elektroda las digunakan sebagai pakan las atau sebagai logam pengisi pada proses pengelasan berlangsung.

Langkah - langkah kegitan pengabdian masyarakat ini bisa dijelaskan pada diagram alir dibawah ini.

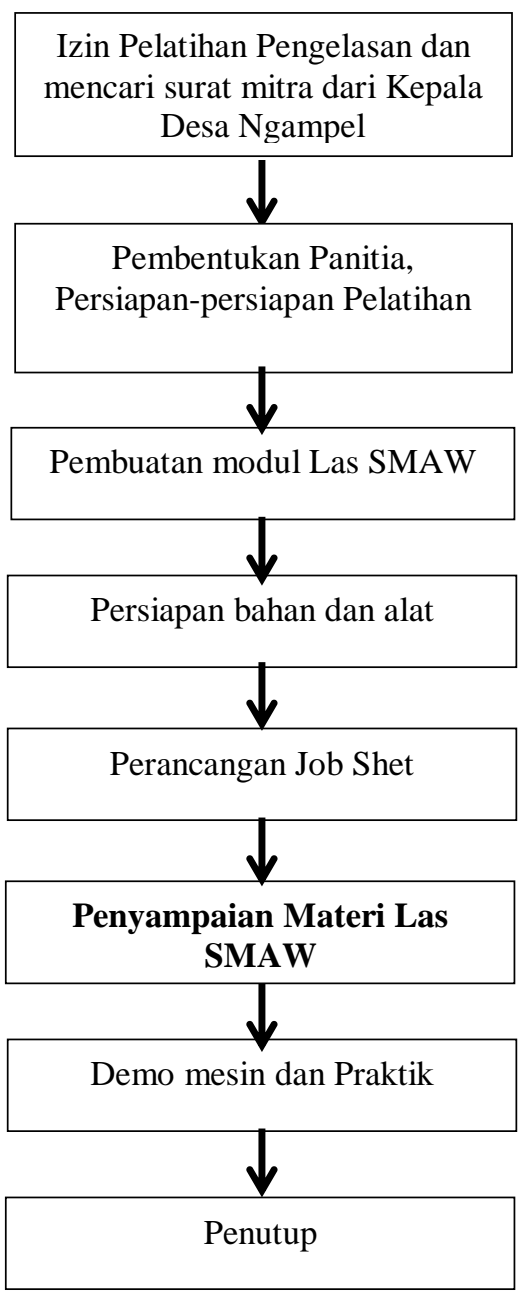

Gambar 2 Diagram Alir Pengabdian

Masyarakat

Metode pengumpulan data dilakukan dengan cara observasi atau mengamati dari peserta pada saat melakukan pekerjaan yang dimulai dari persiapan bahan, pengukuran bahan, pemotongan bahan, pengerjaan job shet sampai proses reparasi.

\section{HASIL DAN PEMBAHASAN}

Hasil kegiatan pengabdian di Desa Ngampel, Kecamatan Ngusikan, Kabupaten Jombang sebagai berikut: 
1. Proses Pemotongan Bahan

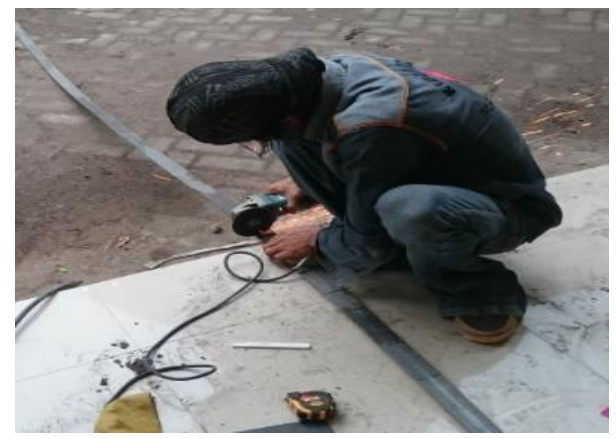

Gambar 11. Proses pemotongan bahan

2. Proses Pembuatan Sambungan Las

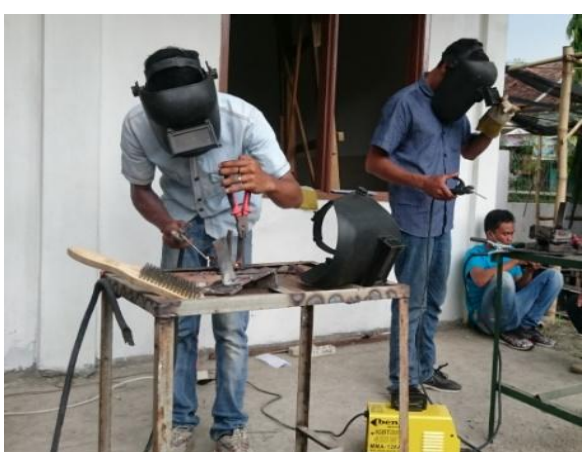

Gambar 12.Pembuatan sambungan las

3. Proses Pengelasan Ayunan

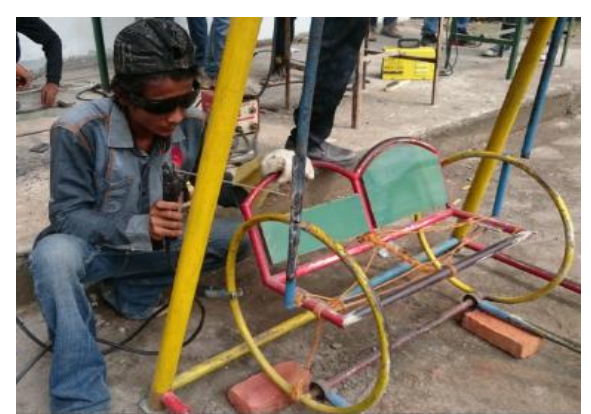

Gambar 13. Pengelasan Ayunan
4. Proses Pengelasan Rak Sepatu

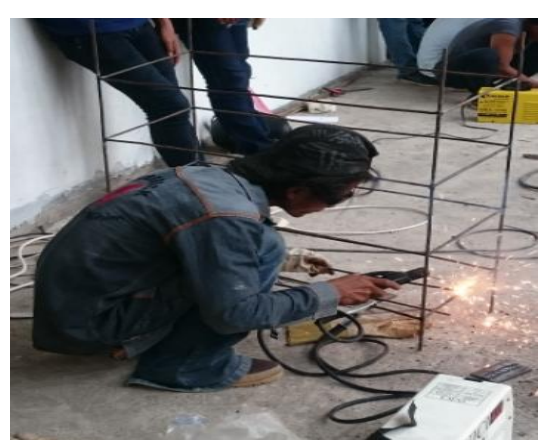

Gambar 14.Pengelasan Rak Sepatu

\section{SIMPULAN}

Dari kegiatan pelatihan pengelasan ini dapat diperoleh kesimpulan sebagai berikut:

1. Dapat meningkatkan keterampilan pemuda karang taruna Desa Ngampel dalam proses pengelasan.

2. Dapat memberikan bekal pemuda karang taruna Desa Ngampel dalam berwirausaha.

\section{DAFTAR PUSTAKA}

https://www.beritasatu.com/nasional/553406/p enganggur-terdidik-meningkat, diakses tanggal 19 September 2019.

http://www.pengelasan.com/2014/06/

pengertian-proses-las-smaw-adalah.html, diakses tanggal 18 Februari 2020.

https://id.wikipedia.org/wiki/Las listrik, diakses tanggal 18 Februari 2020.

Srwidharto.1987. Petunjuk Kerja Las.Jakarta : PT. Prandya Paramita.

Sukaini,Tarkina dan Fandi. 2013. Teknik Las SMAW Untuk SMK / MAK Kelas X. Jakarta: Kementerian dan Kebudayaan. 


\title{
KEPENULISAN CERPEN SANTRI PONDOK PESANTREN PUTRI TEBUIRENG DENGAN STRATEGI PSIKOLIGI KOMUNITAS
}

\author{
${ }^{1}$ Alfian Setya Nugraha, ${ }^{2}$ Rusli Ilham Fadli, ${ }^{3}$ Resdianto Permata Raharjo, ${ }^{4}$ Raras Hafiidah Sari, \\ ${ }^{5}$ Agus Sulton \\ 1,2,3,4,5 Pendidikan Bahasa dan Sastra Indonesia FIP, Universitas Hasyim Asy’ari Tebuireng Jombang \\ ${ }^{1}$ alfiansetyanugraha@gmail.com
}

\begin{abstract}
The purpose of this community service activity is to assist students in understanding the writing of short stories in Pondok Putri Tebuireng Islamic Boarding School in Jombang. This is one of the obligations of educators in order to solve social problems that have occurred in the community in the last period. Community service activities are carried out using the lecture method and discussion of the opinion writing, short stories, and reviews. In addition, participants were also given the opportunity to discuss with the speakers and other participants.
\end{abstract}

Keywords: short stories, female students, community psychology

\begin{abstract}
Abstrak
Tujuan diadakannya kegiatan pengabdian kepada masyarakat ini adalah untuk mendampingi santriwati dalam memahami kepenulisan cerpen yang ada di Pondok Putri Pesantren Tebuireng Jombang. Kali ini merupakan salah satu kewajiban pendidik dalam rangka menyelesaikan permasalahan sosial yang dalam kurun waktu terakhir ini terjadi di masyarakat. Kegiatan pengabdian kepada masyarakat ini dilaksanakan dengan menggunakan metode ceramah dan diskusi tentang kepenulisan opini, cerpen, dan resensi. Selain itu, peserta juga diberikan kesempatan untuk berdiskusi dengan para pemateri dan peserta yang lain.
\end{abstract}

Kata kunci: cerpen, santri putri, psikologi komunitas

\section{PENDAHULUAN}

Amanat Undang-Undang Nomor 20 Tahun 2003 tentang Sistem Pendidikan Nasional menyebutkan bahwa perguruan tinggi berkewajiban menyelenggarakan pendidikan, penelitian, dan pengabdian kepada masyarakat (Pasal 20 Ayat 2). Pelaksanaan pengabdian masyarakat sebagaimana dimaksud diatur dalam Undang-Undang Pendidikan Tinggi No.12 Tahun 2012, yaitu pengabdian masyarakat adalah kegiatan sivitas akademika yang memanfaatkan ilmu pengetahuan dan teknologi untuk memajukan kesejahteraan masyarakat dan mencerdaskan kehidupan bangsa.

Program pengabdian kepada masyarakat merupakan salah satu program yang wajib dilaksanakan, baik oleh dosen maupun oleh mahasiswa, dengan berlandaskan pada prinsipprinsip:

kompetensi akademik, jiwa kewirausahaan

(entrepreneurship), dan profesional, sehingga dapat menghasilkan program pengabdian kepada masyarakat yang bermutu, relevan, dan sinergis dalam meningkatkan pemberdayaan masyarakat.

Pengabdian kepada masyarakat merupakan salah satu dharma atau tugas pokok dari suatu perguruan tinggi, termasuk disamping dharma pendidikan dan pengajaran serta dharma penelitian. Pelaksanaan dharma pengabdian kepada masyarakat yang dalam realisasinya juga melibatkan dua dharma lainnya. Pengabdian masyarakat merupakan kegiatan yang memanfaatkan ilmu pengetahuan dalam upaya memberikan sumbangan demi kemajuan masyarakat. Pengertian mengenai pengabdian masyarakat secara filosofis sesungguhnya dapat berkembang dan dikembangkan sesuai dengan 